\title{
IMPERIALISM, BEAUTY AND CULTURAL IDENTITY
}

\section{B H. V. N. LAKSHMI \& ZAINAB ABDULAZIZ A L SUHAIBANI}

Department of English, Al Qassim University, Buraidah, Kingdom of Saudi Arabia

ABSTRACT
Beauty is an abstract idea with no specific definition and dimension, yet it intrinsically moves the entire person
'spirit and heart, intelligence and reason, creative capacity and imagination.' One's perception of beauty is to a large
extent based on one's cultural identity. But with the passage of time, standards of beauty have changed, disfiguring the
cultural identity and causing chaos and confusion. In India and Africa, people still adopt white standards of beauty.
Though these colonized countries are freed and emancipated, their psyche is yet to be decolonized and restored to their
original selves. Is it not true that the malaise lies with imperialism? Imperialism is such a destructive political ideology
that it not only exploited the economic resources of occupied lands but also destroyed the cultural identities of the
subjugated population to perpetuate the regime. Hence, this paper focuses on how imperialism impacted the standards of
beauty and analyze various aspects associated with it.
KEYWORDS: Ideology, Concept, Myth, Ugly, Fairytales \& History

Received: Oct 27, 2017; Accepted: Nov 17, 2017; Published: Nov 28, 2017; Paper Id.: IJELDEC20177

\section{INTRODUCTION}

Imperialism is such a destructive political ideology that it not only exploited the economic resources of occupied lands but also destroyed the cultural identities of the subjugated population to perpetuate the regime. The modern ideology is more draconian than the earlier one. In the ancient times the idea of cultural identity and the individual psychological profile are not strong enough to distract the public. They moved along with the tides and accepted the ruler's whims and fancies and led their lives in mimicking them. The characters like Cleopatra of Egypt and Helen of Troy invested their charm and beauty in expansion of their kingdom or protecting their boarders or winning the hearts of the rulers. But in modern times the concept of beauty started devouring the individual's inner life and distorted their imagination. In the continents like Asia and Africa, the people are standardizing the model of beauty with the measurement of European and American population. Every nation has its own culture and idea of beauty. When a black woman wanted to become beautiful she cannot expect the skin of a white person. They have to settle with their own standards of life and colour of their skins. In Toni Morrison's The Bluest Eye, a black girl aspires for the bluest eyes thinking that it will make her beautiful and lovable. The idea of beauty is always proven to be destructive, from Cinderella to Cleopatra beauty, played havoc with their lives.

To understand the nature of beauty from myth, history and fairytales, one has to go through the stories of Helen of Troy of Trojan war fame; Cleopatra, the most beautiful consort of Julius Caesar and Mark Antony; and Cinderella, a beautiful maiden from the fairytale, who represents the dreams of young girls. Helen of Troy, no doubt is a mythological character present in Homer's Iliad and Odyssey and her beauty is the result of a divine design. Everyone knows the story that, Helen is the princess of Sparta and she is the most charming and intelligent. Her beauty becomes a burden for her father, as all eligible princes wanted to marry her and they are jealous of 
anyone other than him, who tried to woo her. With great difficulty her father makes a compromise among the chamber of princes that Helen will choose one among them and all others should protect them under the Oath of Tyndareus. After the oath was sworn by all suitors, Menelaus is chosen to be Helen's husband. Eventually she becomes the Queen of Laconia, the wife of King Menelaus.

After giving birth to a daughter and three sons, as she is ordained in the heavens she runs away with Paris, the prince of Troy and the Trojan War ensued. In that war most of the famous heroes are destroyed and ten years of battle ends with the death of Paris and restoration of Helen to her husband. But one can imagine what kind of life Helen might have led after reuniting with her husband. She was seduced by many and reduced to a characterless woman. So, one can see that in the days of mythology, a woman of beauty is not at ease with herself.

Even in Hindu mythology of the Ramayana and the Mahabharata, the stories of Sita and Draupadi led to bitter battles and reduced the empires to nothingness. Sita, the consort of Lord Rama, is the most beautiful woman. She is a woman of great character and high morals. When she chose Rama as her lord, the other princes feel humiliated. Later she was abducted by Ravana, the arch villain in the Ramayana and that resulted in the complete annihilation of the most beautiful empire Lanka. In the Mahabharata, Draupadi is the common wife of the Pandavas and her modesty was outraged first by Keechaka and later, by Kauravas and the death and destruction follows. So, in myth and fairytales, it is always beautiful women and maidens that suffer. Even though, there is semblance of restoration to normalcy, the scars are too deep and they couldn't lead normal life thereafter. Hence, it raises a question whether beauty is a boon or a bane.

The story of Cleopatra, the last Pharaoh of Egypt, is no different from that of Helen of Troy. Cleopatra was married to her younger brother when she was eighteen years old and the vaulting ambition in her prompted her to terminate her own husband. Later, to protect Egypt from the imperialistic Roman Empire, she giftwrapped herself and presented to Julius Caesar. Young and beautiful Cleopatra fascinated Caesar who is around 54 years of age at that time and he passionately fell in love with her. He ensured the protection of Egypt and he remained in Egypt with her for a time. Shortly after, Cleopatra gave birth to a son, Caesarion. At one particular point of time Cleopatra insisted Caesar to shift the capital of Roman Empire from Rome to Alexandria, Egypt. That is not acceptable to most of the Romans and that became one of the reasons to hatch a conspiracy to assassinate Caesar.

Some of the modern historians argue that Caesar engineered his own death as he is failing miserably as a man and feels belittled in the presence of Cleopatra. Whatever the reason might be Caesar walked into his own death trap and once again Cleopatra's status and that of Egypt became uncertain. Searching for allies among Rome's new leaders, she was delighted when Marc Antony, one of Caesar's heirs-apparent, sent for her. Marc Anthony fell head over heels for the Egyptian queen and for nearly seven to eight years their romance and marriage ensured the safety and security of Egypt. But later, again the Roman forces tried to occupy Egypt and in ensuing war Antony and Cleopatra lost many battles. At the end some miscommunication proves fatal for both. With Cleopatra's death, the fate of the Ptolemaic dynasty was sealed, and Egypt fell firmly into Roman hands.

In the story of Cinderella, the beautiful girl Cinderella is harassed by her step mother and two half-sisters for her beauty. They never provide her even proper clothes or food. She is always locked up in a kitchen room. Like in all fairytales, a Godmother appears and turns mice into horses, a pumpkin into a chariot and with the touch of magic wand gets very beautiful clothes to Cinderella. With all that pomp Cinderella goes to the royal ball and dances with the Prince Charming. He instantly falls in love for her beauty but Cinderella has her limitations. The magic cannot last forever. Before 
it is midnight she runs away from the ball and in the process she loses one of her shoes. The Prince wanted to find out the girl whose leg fits well into the shoe. After a long search and painful waiting for Cinderella, the Prince gets united with her. As in every fairytale finally it is like all is well that ends well. But one has to keep in mind that Cinderella suffered in her childhood and adult life just because she is more beautiful than her half-sisters.

Myths and fairytales are innumerable in all cultures. The story of Helen of Troy or the fairytale of Cinderella are not unique to western societies. The idea of 'the beauty and the beast' is perennial in all literatures. Every culture evolves its own Cinderella to give representation to the poor and marginalized sections of the society. Toni Morrison experimented on different ideas of beauty in her novels. In her first novel The Bluest Eye, she created Pecola, a young child, who is considered to be ugly by her own mother. She is teased and terrorized by different characters in the story for her ugliness. No child can be ugly. It is the ugliness of the adults that attributes the physical quality of ugliness to the innocent. If a mother cannot accept her own daughter one can imagine what kind of life the child goes through. Pecola's mother, Pauline, is a creature of white cinemas and she even slaps her own girl to pacify another white child. Even the black women in the community ill-treat her. Louis Junior, the son of Geraldine, a propertied black, lures innocent Pecola into his 'clean' house and enjoys sadistic pleasure by beating her with his mother's cat. When suddenly his mother enters the house he accuses Pecola of killing the cat. Furious and also unable to acknowledge kinship with poor and ugly Pecola, Geraldine shouts "You nasty little black bitch. Get out of my house" (Toni Morrison, 1970). And in the end when her father raped her it is the last straw in her sanity. In her madness she believes that her eyes are not only blue but the bluest and slips away into the deepest isolation.

Morrison's narration and presentation of her characters slowly derange them into madness. The obsession for bluest eyes destroys young Pecola in The Bluest Eye. In another novel Sula, a girl Sula rebels against established norms, asserts her individuality but in the end she becomes a sexual seductress and dies a miserable death. In Song of Solomon, a young girl, Hagar, falls deeply in love with Milkman and withers away when her beauty fails her to own him. Jadine in Tar Baby becomes a model of beauty, under the protection of a white master, Valerian Street. When she encounters the primitive, sensual Son, romance blooms and she enchants Son to travel to New York with her for a while. But later the nightmarish visitation of her own cultural ancestors in Eloe frightens her and she prefers her white makeup to her pigmentation. Running away from Son and her own culture she goes back to New York city, a graveyard of black culture.

In the story of Jazz, every character is moved by jazz in one way or other which is both liberating and perilous. The beautiful young girl Dorcas is shot by Joe Trace who loved her and feels jealous of seeing her dancing with another man. His wife Violet sees Dorcas as the sole cause of Joe's unfaithfulness and tries to stab the dead face of Dorcas at her funeral. Obsessed with the stories of 'golden boy' narrated by her grandmother True Belly, Violet dreams of the golden boy's love and desires of being white. She, like Pecola, denies her blackness. In the intricate web of relationships, the violent love that leads to Dorcas' death exposes Violet's true identity. Morrison also epitomizes the beauty of motherhood in characters such as Eva Peace, Pilate, Baby Suggs, Ondine, Theresa, Consolata etc. addressing them as 'tar woman.' She emphasizes on their selflessness and strength not to romanticize their limited opportunity for adventure or fulfillment outside the boundaries of their own communities, but to show the value and the difficulty of the role that they did serve. She says that they are the heroines of her fiction.

Beauty should not be assessed on the basis of the anatomical statistics. It is not in the color of the skin or the eyes or the hair. The physical beauty is transitory and has many limitations but it opens a gate to exhibit one's inner beauty. 
As Thomas Overbury writes in his poem The Wife, that:

Good, is a fairer attribute then white,

'Tis the minds beauty keeps the other sweete;

Even Shakespeare goes to that extent of saying that beauty herself is black. In his Sonnet 132, he swears allegiance to the woman's beauty and calls "foul" all other women whose looks are not as black as the Dark Lady's.

Then will I swear beauty herself is black,

And all they foul that thy complexion lack.

However, it is not easy to ignore the way imperialistic forces instrumented marginalization of morals. Even in the film industry which boasts of promoting art and culture, sex appeal became a key element in determining the beauty of the actresses in particular. Emulating the western style in dressing as well as speaking is not just a fancy but also a novelty. Sex and beauty are intertwined, especially when determining the ideals of the present day culture. The picturization of physical beauty on silver screen took different dimension. Consequently today, the iconic beauties of Indian movie that could turn heads on red carpet in Hollywood are not Indian in their outfits. This evidently shows how we are increasingly becoming rootless. Ramp walks, beauty contests and red carpets are strongly highlighting the idea of physical or external beauty. Though physical beauty is transitory, if one can use it to exhibit one's inner beauty, it shines eternal.

No good woman or man was ever considered to be ugly. Mahatma Gandhi, Mother Theresa, and Nelson Mandela in our own time, even though they are not handsome and beautiful, are certainly the most beautiful people we ever know. Their simplicity and their inner strength to help the poor and to fight the injustices always put them on a high pedestal. One of the popular cinema heroes in India, Mr. Kamal Hasan, was once questioned about the most beautiful woman in his life and he instantly replied it is Mother Theresa. That sums up the nature of beauty one must aspire for.

Beauty contests and beauty pageants became important tentacles of economic imperialism of developed nations. They not only recommend western body measurements but also impose their dressing sense. It created unrest in the third world societies. Every nation evolves its own dress pattern keeping in mind the cultural needs and the climatic conditions. The western models with flawless skin and thin seductive appearance promote products such as jeans, shoes, leather jackets etc., are invariably stimulating male aggression in otherwise passive society. In recent years it increased the violence against women in multifold. A select number of beautiful women models in these costumes and cosmetics were promoted in the cinema industry to give wider appeal. This however injected an obsession into the society in general and women in particular that beauty is quantifiably scored. Hence, mimicking of the beauties on the screen came into vogue though it is unrealistic to attain. It resulted in the boom of cosmetic industry and the eventual economic strain on the middle class families stripped their family security.

It is a fact that the traditional godly reverence attributed to beauty got faded as globalization advanced. Talking about her documentary film 'The Illusionists' on US channel MIC, Italian filmmaker Elena Rossini says, "Western beauty ideals - actually, man-made Western beauty ideals — have spread to the rest of the world through globalization and are now being upheld as models even in places like India and Japan. And they have very dangerous consequences (Julie Zeilinger, 2015)." No wonder that the famous paintings of Ravi Varma's that stood as a symbol of cultural beauty at one time in India are no more models of beauty today. Barbie dolls and pageant shows caught the attention of modern world. 
Consequently, 'dieting' became a buzz word and zero size became a target size in glamour world, pushing modern beauties into starvation. Dr. Tetsuya Ando of the National Institute of Mental Health states in the documentary film 'The Illusionists' that today about $30 \%$ of Japanese women in their 20 s are categorized as underweight. Globalisation shrinks the world in more ways than we think (Julie Zeilinger, 2015).

Lei Zhang in one of her research papers stated that 'Eurocentric ideal of beauty, with its institutional and historical roots, now serves as a form of structural violence by constricting Asian women, inflicting onto them harmful psychological effects, and leading them to choices such as plastic surgery (Lei Zhang, 2013).' Commonly desired cosmetic surgeries by most women are liposuction, breast augmentation (augmentation mammaplasty), nose reshaping (rhinoplasty) - it involves the breaking and readjustment of the nose bone. Many women will do this in order to change their nose to look more sharp and pointy eyelid surgery (blepharoplasty), tummy tuck (abdominoplasty), facelift (rhytidectomy), breast lift (mastopexy) and removing scars (dermabrasion) (Funk, 2014),. Primarily, these modern treatments aimed at correcting some of the natural deformities, regaining normal appearance after certain accidents and treating health issues such as obesity. But gradually these surgeries turned into a magic wand for many who are aspiring to enhance their physical beauty. They are not only expensive but often hazardous with considerable mortality rate. In some cases, these surgeries might not give the desired results and might cause infections, allergies and heavy bleeding. People who think that these surgeries would make them look like celebrities are living in a fool's paradise.

In the world of beauty contests the country, Venezuela has been shining bright. It has produced many successful beauty queens, winning both Miss Universe and Miss World five times - and Venezuelans see nothing wrong in girls as young as four attending beauty schools to set them on the road to stardom. The country's preoccupation with a modern beauty ideal and personal hygiene is closely related to a colonial complex of idealizing European (white) culture.

The negative aspect of beautification and perfection is well depicted in Nathaniel Hawthorn's story The Birthmark in which Aylmer, a scientist, gets obsessed with removing a birthmark from his wife's cheek. After experimenting many days in his laboratory he prepares a potion that can make his wife, Georgiana, a flawless beauty. Georgiana drinks the concocted potion and promptly falls asleep. Aylmer observes the birthmark fading gradually but the potion has side effects and Georgiana dies once the birthmark fades completely. Obviously the story rings alarm bells for those who chases perfection ignoring the truth. However, the present day reality is that the number of cosmetic surgeries is increasing by scores every year across the globe. Marching towards globalization, humanity needs to assimilate the fact that physical beauty is just an external attribute. Beneath the skin we all are same and yet all different. We need to respect and protect the diversity. Beauty does inspire but never it does, at the cost of one's life and identity.

\section{REFERENCES}

1. Zeilinger, Julie (Feb. 27, 2015). "The Disturbing Effect Our Beauty Standards Have on Women Across the World" retrieved Jan. 2017 from https://mic.com/articles/111228/how-western-beauty-ideals-are-hurting-women-across-the-globe\#.1ZbUqSkPl

2. Betts, Hannah. "Beauty industry: a stealth imperialism with self-harm its main weapon." Retrieved Jan. 2017 from https://www.theguardian.com/commentisfree/2012/aug/29/cosmetic-surgery-imperialism-women-misery

3. Zhang, Lei (2013). Eurocentric Beauty Ideals as a Form of Structural Violence: Origins and Effects on East Asian Women. Retrieved Jan. 2017 from http://twp.duke.edu/uploads/media_items/leizhang-delib2013.original.pdf

4. Funk, M,. (2014). The Westernization of Chinese and Japanese Beauty. Retrieved Jan. 2017 from 
http://www.augustana.edu/documents/ethics/funk_michelle.pdf

5. "Cultural Imperialism : Beauty from the West to East" retrieved Jan. 2017 from https://communicationtechnology101.wordpress.com/2016/03/24/cultural-imperialism-beauty-from-the-west-to-east/

6. Alibhai-Brown, Yasmin. "Why are Asian women aspiring to western ideals of beauty?" retrieved Jan. 2017 from http://www.independent.co.uk/life-style/fashion/features/why-are-asian-women-aspiring-to-western-ideals-of-beauty$\underline{2136868 . h t m l}$

7. "Helen of Troy - Greek Mythology.” Retrieved Jan. 2017 from https://www.greekmythology.com/Myths/Mortals/Helen/helen.html

8. “Cleopatra.” Retrieved Jan. 2017 from https://en.wikipedia.org/wiki/Cleopatra

9. Hawthorne, Nathaniel. The Birth Mark. Retrieved Jan. 2017 from http://www.online-literature.com/poe/125/

10. “Cinderella." Retrieved Jan. 2017 from https://en.wikipedia.org/wiki/Cinderella

11. Sir Thomas Over bury. 'A Wife.' Retrieved Jan. 2017 from https://www.poemhunter.com/poem/a-wife-4/

12. Shakespeare, William. 'Sonnet 132.' Retrieved Jan. 2017 from http://www.shakespeares-sonnets.com/sonnet/132

13. Morrison, Toni (1970). The Bluest Eye. New York: Holt, Rinehart \& Winston. p. 72

14. (1973). Sula. New York: Knopf

15. (1977). Song of Solomon. New York: Knopf

16. (1981). Tar Baby. New York: Knopf

17. (1987). Beloved. New York: Knopf

18. (1992). Jazz. New York: Knopf

19. (1998). Paradise. New York: Knopf 